\title{
A POLÍTICA DE COLONIZAÇÃO DO IMPÉRIO E A FORMAÇÃO SOCIOECONÔMICA DO VALE DO ITAJAÍ
}

\author{
SETTLEMENT POLICY AND EMPIRE THE SOCIO-ECONOMIC \\ FORMATION OF ITAJAÍ VALE
}

\author{
BRuno Mandelli ${ }^{1}$
}

Recebido em: 08/01/2015 Aprovado em: 18/05/2015

\section{RESUMO}

Este artigo pretende analisar a gênese do processo de industrialização no Vale do Itajaí com base no estudo da imigração alemã que se estabelece na região a partir da segunda metade do século XIX. Com a revisão bibliográfica sobre o tema e também com a análise dos relatórios do presidente da província de Santa Catarina, emitidos entre 1860 e 1889, procurou-se analisar o discurso do Estado quanto à política de colonização nessa região e como essa política estatal está vinculada ao referido processo.

Palavras-chave: Imigração alemã; Política de colonização do império; Industrialização.

\begin{abstract}
This article aims to analyze the genesis of the industrialization process in the Itajai valley from the study of German immigration that takes place from the second half of the nineteenth century. With research-based literature on the subject and also the analysis of the reports of the president of the province of Santa Catarina - between 1860 and 1889 - tried to analyze the discourse of state for political settlement in the region and how that state policy is linked to that process.
\end{abstract}

Keywords: German Immigration; Settlement policy of the empire; Industrialization. 


\section{Introdução}

Quando pensamos sobre o mundo moderno, logo vêm à mente certas palavras-chave: indústria, proletariado, burguesia, mercado, sindicatos, lucro, dentre outras. No momento em que utilizamos certos conceitos para explicar o mundo $\mathrm{e}$, portanto, a linguagem como forma de expressão daquilo que conhecemos, o fenômeno a que nos referimos já possui um significado histórico coletivo.

Diante disso, neste artigo, pretendemos analisar o processo de formação socioeconômica de uma região específica do Estado de Santa Catarina: o Vale do Itajaí. A articulação do processo de industrialização com a imigração europeia da segunda metade do século XIX e os seus nexos internos são o que importam neste estudo.

Os fundamentos teóricos dos quais partimos para a reflexão se estabelecem com base em uma análise ontológica do gênero humano, em que se entende o trabalho não só como transformador da natureza para satisfazer necessidades humanas, mas também como transformador do próprio homem e das relações sociais que ele engendra.

Assim, o aparecimento de certas palavras-chave que servem para explicar o mundo moderno no vocabulário da época apenas demonstra um processo aparente de desenvolvimento do capitalismo enquanto realidade histórica interna. Portanto, quando nos deparamos com os relatórios do presidente da província de Santa Catarina utilizando certas palavras, como "classe proletária", "capitalistas", "indústrias" e "braços livres", na década de 1860 , somos levados a estudar a gênese histórica do que se convencionou chamar de capitalismo, sem o que podemos cair no equívoco de explicar tal processo como expressão do mito do "pioneiro" e do "empresário inovador", tão comum na literatura sobre o tema.

\section{Crise do sistema escravista e emer- gência da emigração europeia}

O processo de alargamento e diferenciação das bases sociais em que o Brasil se assentava até meados do século XIX tornar-se-á visível e aparente apenas no final desse século e início do próximo, quando as primeiras indústrias se consolidam e projetam a imagem de um Brasil industrial. No entanto, a gênese do processo de modernização e de metamorfose do capital mercantil em capital industrial (com todas as consequências sócio-históricas que disso resultam, como a urbanização e o crescimento demográfico, as transformações técnicas e culturais e as transformações no mundo do trabalho com o surgimento do proletariado urbano) lança as suas raízes na transformação que vai se operar a partir da segunda metade do século XIX e início do $\mathrm{XX}^{2}$.

Compreender as transformações que irão se operar nesse espaço condensado de tempo exige que dissipemos algumas questões preliminares acerca da crise do antigo regime colonial e da permanência de estruturas herdadas desse passado. O Brasil formou-se no Atlântico e através dele. O que significa essa frase? Significa que, do século XVI ao XVIII, a expansão da ocupação portuguesa na América assentou-se na estrutura de uma sociedade escravista, que ininterruptamente incorporava escravos e agregados, africanos ou ameríndios, por meio da guerra e da caça, na África ou nos sertões do Brasil. Já é, pois, de conhecimento geral que a economia colonial se formou pautada na exportação de matérias-primas, que incluía em sua unidade fundamental a plantation $\mathrm{e}$ o latifúndio.

A partir do início do século XIX, com o questionamento acerca da es-

2 Trata-se do que Florestan Fernandes irá chamar de "Concretização da Revolução Burguesa": "Na acepção em que tomamos o conceito, ReRevolução Burguesa": "Na acepção em que tomamos o conceito, Re-
volução Burguesa denota um conjunto de transformações econômicas, tecnológicas, sociais, psicoculturais e políticas que só se realizam quando o desenvolvimento capitalista atinge o clímax de sua evolução industrial" (p. 293). FERNANDES, Florestan. A revolução burguesa no Brasil: ensaio de interpretação sociológica. São Paulo: Editora Globo, 2008. 
cravidão enquanto forma de trabalho desumano e a pressão internacional pelo fim do tráfico de escravos (com a Inglaterra encabeçando essa bandeira), instala-se no centro das discussões da classe dominante e do Estado Imperial a preocupação com o fim da escravidão e a necessidade de sua transformação. Vale ressaltar que se tratava de uma discussão muito pouco quista pelas elites e que causava conflitos internos agudos que resultaram na tentativa desesperada de manutenção do sistema escravista: da transferência da Corte portuguesa para o Rio de Janeiro, em 1808, até a abolição da escravidão, em 1888, decorrem 80 anos de prolongamento da escravidão enquanto modo predominante de trabalho ${ }^{3}$.

Nota-se, portanto, que o processo de abolição gradual do trabalho escravo esteve no centro do debate sobre a formação do Estado nacional, como afirma Beatriz Mamigonian: "trata-se de mostrar que os fundadores do império defenderam-se das pressões externas formulando um discurso da necessidade de uma abolição gradual enquanto estruturavam o Estado para defender a ordem escravista" (2009, p. 229).

Com a abolição do tráfico de escravos novos para o Brasil em 1850, em função da Lei Eusébio de Queiróz, ocorre uma profunda transformação na economia nacional. Ainda não se acabara com a escravidão, pois muitos cativos ainda perdurariam como a última geração do sistema escravista. Porém, eram necessários novos braços para garantir a reprodução do sistema agroexportador agora não mais com o açúcar, mas com o café, e não mais com o escravo negro, mas com o imigrante europeu mal remunerado. A partir de então, inicia-se uma profunda transformação que lançará as bases para o desenvolvimento do capitalismo no Brasil: a necessidade de substituição da mão de obra escrava

${ }^{3}$ Inúmeras leis e contratos foram firmados para a proibição do tráfico de escravos no período: Tratado de Aliança e Amizade (1810); Congresso de Viena (1815); Tratado de abolição do tráfico de escravos (1827); Projeto de Lei de proibição do tráfico (1831); Lei Eusébio de Queirós (1850); Lei do Ventre Livre (1871); Lei dos Sexagenários (1885); e Lei Áurea (1888). pelo trabalho assalariado.

Assiste-se, a partir dessa época, a uma mudança geográfica profunda no processo emigratório para o Brasil: estanca-se o tráfico de escravos negros vindos da África e inicia-se a emigração europeia de trabalhadores livres, principalmente italianos, alemães e portugueses. Essa será, portanto, a base da transformação do modo de produção escravista para o modo de produção capitalista, em meio a algumas peculiaridades históricas.

A questão da imigração europeia, que se tornará "o começo da maior migração de povos na História" (HOBSBAWN, 2011, p. 295), forma, portanto, uma unidade contraditória inseparável da escravidão e do seu processo de abolição. Cabe analisar, dessa forma, a gênese das transformações socioeconômicas que resultarão na saída de milhares de homens e mulheres de seu país de origem, bem como o destino, muitas vezes incerto, de uma nova realidade estranha e desconhecida.

\section{A política de colonização do Império}

Vimos como a decadência do regime escravocrata exigia soluções estruturais no modo de produção do país. Não adiantava mais emitir algumas leis que serviam apenas para atenuar o problema ou para the dar uma sobrevida, sem, no entanto, uma solução definitiva e de longo prazo. As transformações que decorreram da crise do sistema escravista, das quais a imigração europeia massiva é uma resultante que passa a ser promovida pelo Governo Imperial como uma política de Estado, constituem o foco de nossa análise a partir de agora. A necessidade de novos braços para a lavoura, principalmente nas lavouras de café em São Paulo, bem como a preocupação com o "branqueamento" daquela população mestiça, consiste no marco decisivo para a consolidação da corrente imigratória no Brasil a partir do século XIX, com mais intensidade 
na sua segunda metade.

As primeiras tentativas de trazer esses colonos resultaram em um sistema de parceria com os proprietários de terras, na maioria dos casos (ex)senhores de escravos, no sudeste para trabalharem na lavoura cafeeira. No entanto, a forma do trabalho gerou muitos conflitos sociais entre imigrantes e proprietários, visto que estes tratavam os imigrantes como semiescravos: violência, salários baixos, superexploração. Como descreve Caio Prado Jr.:

Os proprietários, habituados a lidar exclusivamente com escravos, e que continuavam a conservar muitos deles trabalhando ao lado dos colonos, não tinham para com estes a consideração devida à sua qualidade de trabalhadores livres; os contratos de trabalho que os imigrantes assinavam antes de embarcar na Europa e desconhecendo ainda completamente o meio e as condições do país onde se engajavam, eram geralmente redigidos em proveito exclusivo do empregador e não raro com acentuada máfé (1976, p. 187).

É certo que o número de imigrantes que vieram para se incorporar à grande lavoura e a forma de trabalho que se estabelece a partir dessa relação - como é o caso do meeiro - superaram os destinos daqueles que vieram para se instalar como pequenos produtores, que encontraram na agricultura familiar a produção de alimentos para o mercado interno. Caio Prado Jr. afirmou que, “em conjunto, a 'imigração' (no sentido restrito dado a palavra) superará sempre, de muito, a colonização"" (1976, p. 190).

Por mais que essa avaliação esteja correta, ela é insuficiente para explicar por que a colonização de pequenas propriedades assumiu espaço significativo na política do Império brasileiro, "chegando ao ponto de, no ano de 1878 , o Governo Imperial aplicar aproximadamente $10 \%$ de seu orçamento" (MACHADO, 1999, p. 13). Assim, a atenção principal do Governo Imperial volta-se, na segunda metade do século XIX, para garantir uma corrente de imigração europeia para o Brasil.

Nessa época, o Brasil vivia um período de crescimento econômico, impulsionado pela expansão da lavoura cafeeira e dos altos preços que o produto atingia no mercado externo. O papel antes consagrado pelo açúcar passa agora a uma nova mercadoria: "A lavoura do café marca na evolução econômica do Brasil um período bem caracterizado. Durante três quartos de século concentra-se nela quase toda a riqueza do país" (PRADO JR., 1976, p. 167).

Essa conjuntura favorável ao crescimento do setor agroexportador será ampliada por uma capacidade de investimento maior do Estado Imperial, pois as principais receitas do Estado eram provenientes do comércio de importação e exportação. No conjunto, essa situação abria a possibilidade de resposta para diversos problemas ou "pontos de estrangulamento", que, se não resolvidos ao cabo de alguns anos, poderiam inviabilizar o crescimento do país.

Estes pontos de estrangulamento eram a questão da mão de obra escrava (com o fim do tráfico e seu crescimento vegetativo negativo), uma política de terras (apenas formalmente equacionada com a Lei de Terras de 1850), uma política de desenvolvimento interno (investimentos em portos, ferrovias e urbanização) e uma política de imigração - ligada tanto à questão de terras, quanto ao incremento e diversificação do mercado interno brasileiro (MACHADO, 1999, p. 64).

Uma das respostas para enfrentar a questão legal da distribuição de terras no Brasil ocorreu com a Lei de Terras de 1850, que dispunha sobre a utilização das terras devolutas, as quais deveriam ser vendidas por meio de um financiamento que o colono contraía para ser pago nos anos seguintes à sua 
instalação.

Na formação do Brasil meridional, particularmente em Santa Catarina, a imigração assume um caráter diferente do restante do país. Nessa região, não havia a economia da grande lavoura, como no sudeste e no nordeste brasileiro.A formação econômica catarinense, excetuando-se o planalto e o meio-oeste (que foram ocupados por meio das frentes pastoris de criação de gado), não é constituída dos grandes latifúndios produtores de produtos tropicais. Portanto, não era como assalariado dos antigos senhores de escravos que se fixavam os imigrantes provenientes da Europa, mas como pequenos agricultores produzindo para a subsistência e para comercialização do excedente:

Constitui-se assim, nesta parte do Brasil, um setor cuja organização econômica e social é bem distinta da do resto do país: grande parcelamento da propriedade fundiária, ausência do latifúndio; em vez de grandes lavouras do tipo do café, do açúcar ou do algodão, que produzem, sobretudo para o comércio exterior, pequenas culturas e outras atividades de caráter local e destinadas ao abastecimento interno do país: cereais, vinho, produtos de granja, etc. (PRADO JR., 1976, p. 204).

Em Santa Catarina, a política de colonização em grande escala passou a se dar a partir da metade do século XIX. Com a política Imperial de substituição da mão de obra escrava pela do imigrante europeu, sobretudo com a Lei de Terras, passou-se a acelerar a vinda de imigrantes para o território catarinense. Ao analisar os relatórios do presidente da província de Santa Catarina entre 1860 e 1889, ficam evidentes as preocupações centrais que norteavam a política do Império brasileiro. No relatório de Adolpho de Bassos Cavalcanti de Albuquerque Lacerda, de 1868, ele discorre sobre a colonização, afirmando que, apesar de a imigração não receber aumento notável durante o último ano: estas [colonias] em geral forão dotadas de diversos melhoramentos e não deixarão de prosperar. É disto uma prova o facto, nestes utimos mezes frequentemente repetido, de colonos solicitarem o auxilio do governo para a vinda de parentes e de amigos que havião deixado em sua patria; facto bastante satisfactorio, porque, denotando o bem estar e contentamento desses colonos, concorre poderosamente para acreditar a colonisação brasileira nos paizes da Europa, e nos centros mesmo d'onde procuramos attrahir immigração [...] Tudo quanto se fizer em benefício dos interesses creados redundará necessariamente em proveito da immigração que se promove [...] Quando a prosperidade dellas atingir o gráo que se deseja, a corrente de immgração se estabelecerá por si mesmo, espontanea e abundantemente (grifos nossos). ${ }^{4}$

Temos, portanto, o relato de um homem de Estado, preocupado em estabelecer uma boa imagem da colonização no sul do Brasil para poder atrair mais imigrantes para esse país, seja para a lavoura cafeeira paulista, seja para povoar e estabelecer uma camada de pequenos proprietários rurais no Brasil meridional. Podemos notar, também, que o perfil dos imigrantes dessas diferentes regiões se estabelece principalmente a partir da classe social a que pertencem. Esta é, em geral, uma preocupação tanto do Estado quanto dos diretores das colônias. Em outro relatório do presidente da província Francisco Carlos d'Araujo Brusque, de 1861, é notável a utilização de certas palavras que demonstram o que Weber chamou de "espírito capitalista":

O que falta, pois Senhores, para que esta Provincia se torne em pouco tempo uma das mais ricas Provincias do Imperio? Um systema de colonisação, que attrahindo a emigração européia, não somente composta de

Relatório do Presidente da Província de Santa Catarina, Adopho de Bassos Car canti de Albuquerque Lacerda, 1868, p. 13. 
proletarios, a quem nos encarregamos de fazer proprietarios, mas tambem de capitalistas, venha com seus braços e capitaes fecundar nossas terras, e colher os dons que occultão ellas em seu seio (grifos nossos). ${ }^{5}$

Notamos, portanto, o contínuo desejo de atrair a imigração europeia, não mais apenas com "proletários", mas também com "capitalistas" que tragam seus capitais da Europa para investirem em Santa Catarina. Como mencionamos, era uma constante nesse período a emigração em massa da classe trabalhadora na Europa, tendo em vista o processo de expulsão do campo e do assalariamento forçado a que eram submetidos. Quase dez anos após esse relatório, em 1870, a preocupação com a "classe proletária" é reforçada pelo presidente da província André Cordeiro de Araujo Lima:

Vitaes interesses da Provincia ligamse á Colonisação. Entretanto é de lastimar que as colonias, ao menos algumas, não só, não tenham tido o desejavel progresso, como até tenhão retrogradado, a despeito dos enormes sacrificios feitos pelo Thezouro $\mathrm{Pu}-$ blico, o que parece dever-se attrbuir á falta de uma inspecção activa e intelligente, ou á desidia dos immigrantes, pela maior parte tirados da classe prolectaria da Europa e dos Estados-Unidos da America do Norte, os quaes, acostumados alli a nada fazer, têm vindo para o Imperio manter-se exclusivamente dos subsidios que o Govero lhes dá. Desde que este cessam, retiram-se das Colonias, dirigindo-se principalmente para as Republicas Oriental e Argentina, onde suppoem encontrar recursos que na maioria dos casos lhees falham (grifos nossos). ${ }^{6}$

A partir desses relatos, podemos tirar duas conclusões importantes neste trabalho: o objetivo da política de co-

${ }_{5}^{5}$ Relatório do Presidente da Província de Santa Catarina, Francisco Carlos d'Araujo Brusque, 1861, p. 5.

${ }^{6}$ Relatório do Presidente da Província de Santa Catarina, Andre Cordeiro de Araujo Lima, 1870, p. 14. lonização do Império era construir uma corrente de imigração "espontânea" que destinasse braços livres e capitais tanto para trabalhar na lavoura de café quanto para formar uma camada de pequenos proprietários no sul do país; e dirigir, ao sudeste brasileiro, para trabalhar na lavoura cafeeira, uma corrente de imigração da classe proletária e, portanto, pobre, e, ao sul, imigrantes que já possuíam algum capital, não que fossem capitalistas industriais na Europa, mas que pudessem estabelecer a sua propriedade agrícola, pagar pela terra, pelas ferramentas, etc., onde desejavam que os núcleos coloniais formados contribuíssem para a produção de alimentos e produtos agrícolas para o mercado interno, além de serem funcionais para a atração de novos imigrantes - já que, com colônias bem-sucedidas, o contingente de imigrantes aumentaria.

\section{A colonização no Vale do Itajaí}

Já analisamos a política de colonização do Império e os fatores de atração que proporcionaram o estabelecimento de imigrantes no novo destino, tendo em vista tanto a colonização no Brasil meridional quanto a imigração para a grande lavoura - e como essas duas formas de imigração não eram necessariamente excludentes, porém possuíam uma interação recíproca. Cabe, agora, aprofundar o processo de colonização em uma região específica: a colonização alemã no Vale do Itajaí.

É característico desse tipo de colonização germânica no sul do Brasil o estabelecimento em áreas de floresta situadas entre o litoral e o planalto (SEYFERTH, 1999, p. 29). Essa tendência no processo de colonização germânica ocorreu principalmente porque essas regiões eram ainda de predomínio indígena, sendo uma constante na linha política do Estado a ocupação dessas áreas para colonização europeia, com o duplo objetivo de "civilizar" e de estabelecer uma camada de proprietários produtores 
de alimentos longe do centro de exportação do país. Segundo Giralda Seyferth:

Ao Governo Imperial interessava povoar uma área de florestas com pequenos proprietários agricultores e os esforços de colonização se concentraram nas duas províncias meridionais em virtude da pressão dos grandes proprietários de café quanto à concessão de terras a estrangeiros em São Paulo. [...] Havia uma razão estratégica para que o Governo Imperial destinasse essas áreas à colonização: era preciso abrir vias de comunicação entre o litoral e o planalto e isto só seria viável acompanhando o vale dos principais rios [...] Em Santa Catarina, principalmente, não havia comunicação entre a capital Desterro e o planalto e foi com esta finalidade que se deu estímulo à colonização alemã no vale do Itajaí (SEYFERTH, 1999, p. 31).

Com essa preocupação em vista, o Governo tratou de incentivar a imigração, por meio de colônias tanto oficiais quanto particulares. "A partir daí apresentou-se uma colonização mais estruturada sem a improvisação até então sentida" (PIAZZA; HÜBENER, 1989, p. 70). Na pátria de origem, foi então estabelecida uma companhia colonizadora, e Hermann Blumenau e o comerciante Fernando Hackradt adquiriram uma gleba de terra na região banhada pelo rio Itajaí-Açu e fizeram o aliciamento de alguns colonos na Alemanha. Chegaram em 1850 com 17 imigrantes que desembarcaram no porto de Desterro. "Entre esses dezessete imigrantes havia agrimensor, carpinteiro, marceneiro, charuteiro, funileiro, ferreiro e dois lavradores" (PIAZZA, 1982, p. 115).

Em seguida, foram fundadas as colônias de Dona Francisca (1851) nas terras da Princesa D. Francisca, Itajaí -Brusque (1860) no médio Itajaí-Mirim e Ibirama (1899) no alto Itajaí-Açu. O desenvolvimento das colônias foi favorecido, ainda, pela imigração italiana a partir de 1875 , proveniente de regiões do norte da Itália.

Em relação ao processo de ocupação das terras que formariam o espaço desses municípios, é importante salientar o caráter da pequena propriedade - entre 25 e 30 hectares - e de relativo isolamento que adquiriram nos primeiros anos. Como essas pessoas, em geral, "não procuravam outra coisa senão restabelecer seu modo de vida, ou seja, a posse de sua casinha, de um pedaço de campo" (VIDOR, 1995, p. 52), era natural que, em um primeiro momento, assumissem a postura de se fechar na comunidade de pequenos produtores rurais, onde possuíam conhecimento de seu meio e relacionavam-se com uma comunidade de mesma identidade étnica. Como analisa o sociólogo Florestan Fernandes, "Em consequência, o isolamento cultural operava como um fator de autoproteção, apesar das várias formas de acomodação que envolvia contatos sociais e trocas culturais. Graças a esse isolamento, o imigrante podia fechar-se em si mesmo e em pequenos grupos" (2008, p. 158).

Dessa forma, é característica dos primeiros anos de colonização uma sociedade de pequenos produtores rurais que trocavam entre si a produção a fim de satisfazer as necessidades de subsistência e de reprodução social. No entanto, com o domínio que foram exercendo sobre as forças naturais e o desenvolvimento das relações sociais localizadas e com o avanço das técnicas empregadas tanto na agricultura quanto no melhoramento dos meios de comunicação e transporte, vai se desenvolvendo um processo de troca mais complexo entre essas comunidades, levando ao surgimento do mercado - na figura do vendeiro - e ao planejamento da produção tanto para a subsistência milho, mandioca e feijão - quanto para a comercialização do excedente - fumo e cana-de-açúcar. Como destaca Giralda Seyferth: 
A policultura foi, portanto, adotada desde o início, e, por esse motivo, o colono trabalhava na lavoura durante todo o ano, plantando sucessivamente a mesma roça. Em virtude do isolamento da colônia e da dificuldade de obter mercadorias de primeira necessidade, o colono obtinha na sua propriedade o necessário à sua subsistência, com exceção do sal, roupas e ferramentas. A policultura era condição essencial à sobrevivência e nos primeiros anos só um mínimo de excedente da produção do colono era canalizado para venda (1999, p. 59).

Desse modo, estabelece-se uma comunidade de pequenos produtores rurais, que, com a mão de obra familiar, produzem aquilo de que necessitam para a sua subsistência; contudo, já possuem também o caráter teleológico de produzirem algo para o mercado destinado especificamente para a troca, com o objetivo de adquirirem aquilo de que necessitam e que não podem produzir. Sobre o processo de troca e o desenvolvimento do comércio, Marx afirma que:

A troca de mercadorias começa onde as
comunidades terminam, em seus pon-
tos de contato com outras comunidades
ou com membros de outras comuni-
dades. Tão logo as coisas se tornem
mercadorias no exterior da comunida-
de, tornam-se também por repercussão
mercadorias no interior da vida comu-
nal. [...] A constante repetição da troca
transforma-a em um processo social re-
gular. Com o correr do tempo, torna-se
necessário, portanto, que parte do pro-
duto do trabalho seja intencionalmente
feito para troca. Seu valor-de-uso dis-
socia-se do seu valor-de-troca. Por ou-
tro lado, torna-se a relação quantitativa,
em que se trocam, dependente da sua
própria produção. O costume fixa-as
como grandezas de valor (1982, p. 81 ).

Desse modo, com a constante repetição das trocas e a generalização das mercadorias no interior da comunidade, estabelece-se um vínculo entre os diver- sos produtores individuais com o mercado, em que aqueles, independente de sua vontade, devem recorrer para poderem satisfazer certas necessidades para o próprio consumo imediato ou para a aquisição de utensílios e ferramentas, enfim, de meios de produção necessários para sua subsistência.

Entretanto, dificilmente, algum colono era proprietário de engenho ou atafona, tendo em vista que era necessária relativa quantidade de capital para poder instalar uma pequena fábrica desse tipo. A maioria dos proprietários desses estabelecimentos constituía-se de comerciantes que eram donos das vendas e que controlavam o comércio da região. Cabe destacar que, para os colonos produzirem seus produtos nesses engenhos e atafonas, era necessário repassar metade da produção para o proprietário - uma forma de meia ${ }^{7}$.

Outra forma de trabalho muito comum nesse período era o trabalho na construção de estradas. Os colonos, para poderem sanar as dívidas que haviam adquirido com a viagem para o Brasil, as ferramentas e os demais meios de subsistência utilizados nos primeiros anos, inclusive a terra, eram obrigados a trabalhar alguns meses - principalmente fora do período de plantio e colheita - na abertura de estradas e picadas. Pinheiro Machado destaca que:

Outro expediente empregado pelo regulamento era a utilização do trabalho assalariado dos imigrantes para construção de estradas e obras públicas. Para o Governo Imperial, é uma forma de autofinanciamento e redução de gastos; para o imigrante, é a oportunidade de ganhar algum dinheiro e pagar adiantado pelo lote num trabalho de interesse direto dele e de sua comunidade, ou, simples-

A forma de trabalho estabelecida pelo meeiro é derivada da relação de parceria, que é uma denominação comumente atribuída à relação econô-

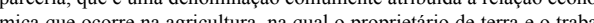
ma ca lhador dividen a produção con base no capital investido pelo proprietário e no serviço empregado pelo trabalhador, podendo ser à meia, em que o trabalhador geralmente é chamado de meeiro, à terça, à quarta etc. Em nosso estudo, verificamos o deslocamento dessa relação de produção para outras atividades além da propriedade da terra, como no caso dos proprietários de engenhos, de atafonas e de serrarias. 
mente, uma forma de sobreviver até a primeira safra (1999, p. 84).

No entanto, acreditamos que não era somente com a redução dos gastos que o Governo estava preocupado ao estabelecer o trabalho do colono nesse tipo de obra pública. Em relatório do presidente da província de 1872 , o então vice-presidente Guilherme Cordeiro Coelho Cintra afirma que:

O emprego dos colonos em trabalho de estradas há concorrido para habitual-os ao salario do operario, e para fazel-os deixar de parte as vantagens que poderão tirar da lavoura, esse apêgo se torna manifesto na immigração de grande numero de colonos que, deixando suas familias vão ás provincias visinhas contratar-se em trabalhos de estrada (grifos nossos) ${ }^{8}$.

Desse modo, ao recorrer ao trabalho dos colonos para obras públicas, como a abertura de estradas que demandava certo tempo, o Estado estava com suas atenções voltadas não só para a redução de gastos ou para a possibilidade de o colono honrar suas dívidas - inclusive, com o próprio Governo -, mas também para "habitua-los ao salario do operário".

O relevante para o estudo que estamos empreendendo é demonstrar a gênese do processo de produção nos núcleos de colonização no nordeste do Estado e o modo como as relações sociais que se engendram a partir de então contribuem para o desenvolvimento do capitalismo enquanto realidade histórica interna.

Alguns autores tentam explicar a origem da industrialização no Vale do Itajaí por algumas vias insatisfatórias. Piazza e Hübener afirmam, por exemplo, que "a predominância de artesãos sobre lavradores talvez explique a tradição industrial que se firmará como base econômica da região" (1989, p. 72). Já Américo Augusto da Costa e Souto tem por perfil do homem que faz a história o "empresário inovador", como ele próprio afirma:

${ }^{8}$ Relatório do vice-presidente da província de Santa Catarina, Guilherme Cordeiro Coelho Cintra, 1872, p. 37.
A História Econômica, uma das preferências da Escola Francesa tem como atores históricos não os heróis políticos e militares, mas sim os heróis "shumpeterianos" das façanhas econômicas: o italiano Mattarazo, caudilho empresarial, é, assim, a réplica do outro italiano, o caudilho revolucionário Garibaldi; o Visconde de Mauá passa a merecer monumentos, ao lado de um D. Pedro I, um José Bonifácio... No nosso caso, os capitães de empresa e técnicos inventores teuto-catarinenses serão os atores da épica industrial (2004, p. 115).

Ainda em relação ao papel do imigrante, o autor destaca que: "Via de regra, não trazia recursos materiais, suas armas para a aventura industrial foram sua mentalidade empresarial e suas qualificações técnicas. Eram capitalistas sem capital" (COSTA SOUTO, 2004, p. 129), grifo nosso.

Poderíamos associar à perspectiva de Costa Souto o proposto pela historiadora Maria Luiza Renaux Hering - pertencente à família dos empresários que fundaram as empresas Hering e Renaux, umas das maiores fábricas têxteis do Brasil -, que estuda a industrialização do Vale do Itajaí a partir da iniciativa dos empreendedores imigrantes que,

sem contar com o favorecimento do governo, canalizaram os investimentos de base rural para a formação de empresas industriais e desenvolveram suas fábricas adotando como princípio de gerência empresarial a aplicação de recursos autogerados, representados basicamente pela capitalização de parcela dos rendimentos familiares (HERING, 1987, p. 318).

O geógrafo Armem Mamigonian, em seu trabalho intitulado Estudo Geográfico das indústrias de Blumenau, explica a gênese da indústria blumenauense a partir da transposição da industrialização em curso na Alemanha, considerando que esse fato bastava para que se instalasse um processo de 
industrialização aqui nos moldes do que ocorria lá:

a colonização alemã em Blumenau trouxe em si mesma a indústria, se se considerar que seus membros, provenientes de uma civilização em pleno desenvolvimento industrial, trouxeram eles mesmos esta civilização [...] Assim, pode-se dizer que se a colonização do Dr. Blumenau, por causa da sua riqueza humana, no lugar de ser Santa Catarina, se localizasse não importa onde, os resultados seriam os mesmos (MAMIGONIAN, 1965, p. 416, grifos do autor).

Goulart Filho, por sua vez, não cai na apologia de explicar a gênese da industrialização com base no "empresário inovador" ou na transposição simplista da Revolução Industrial em curso na Europa para a realidade brasileira. Ele explica que

o crescimento de inúmeras pequenas atividades manufatureiras deve ser entendido pelo parcelamento da propriedade, pelo alto grau de difusão tecnológica dos adventos da Primeira Revolução Industrial (facilidade de cópia) e pela tradição dos imigrantes que eram provenientes de regiões industriais da Alemanha e de regiões industriais e agrárias da Itália (GOULART, 2007, p. 52).

Consideramos que tais análises contribuíram para a pesquisa e reflexão histórica. Entretanto, limitam-se à aparência dos fenômenos, não adentrando na essência, ou seja, na explicação da gênese da industrialização.

Nesse momento, a produção nas colônias estava fundada na pequena propriedade familiar, que produzia diversos gêneros agrícolas, dos quais a maioria estava voltada para a subsistência - produção de valores de uso - e a minoria para a venda no mercado - produção de valores de troca.

Com a vinda dos emigrantes para a região, foram se estabelecendo não ape- nas agricultores e artesãos, mas também comerciantes que já possuíam algum capital na Europa. Como ressalta Vidor, "Existiam, entre os imigrantes, pessoas de origem urbana, exercendo antes, em seu país, funções ligadas ao comércio e à pequena indústria" $(1995$, p. 52$)$.

Os "vendeiros", como eram chamados, não eram apenas intermediários que realizavam a troca das mercadorias, mas constituíam-se em verdadeiros senhores da economia local, uma vez que eram proprietários de engenhos, serrarias e atafonas e exerciam o controle das vendas em pouco número, além de monopolizarem a função do crédito e da poupança em suas mãos, uma vez que, como não existiam "bancos" propriamente ditos, os comerciantes realizavam as transações financeiras, realizando empréstimos, cobrando juros, "guardando" o dinheiro e produtos agrícolas. Além disso, "os vendeiros exerciam uma espécie de domínio cultural e político, além do econômico, pois eram também donos da notícia" (SEYFERTH, 1999, p. 59).

É importante constatar, portanto, que a acumulação de capital proporcionada pelo comércio constitui-se em apenas umas das vias pelas quais o comerciante realiza o seu progresso econômico. Como era relativamente difícil o transporte e a comunicação entre a colônia e outras vilas próximas, era preponderante o papel do capital mercantil nessa fase inicial de colonização: deter o controle do comércio local e sua ligação com outras regiões; controlar o crédito e a poupança dos pequenos proprietários; e receber cerca de metade dos produtos produzidos nos engenhos e nas atafonas - quando possuíam a propriedade desses meios de produção - constitui, dessa forma, uma alavanca no processo de acumulação primitiva necessária ao posterior investimento industrial. Em síntese:

Resumindo a atividade comercial na área, podemos dizer que a venda 
combinava as funções de local de troca (mercado), local de estocagem de produtos agrícolas e o vendeiro concentrava ainda nas mãos um sistema de crédito e financiamento fundamentado na sua condição de intermediário que avoluma e transporta uma parte da produção camponesa que lhe é entregue em pequenas quantidades (SEYFERTH, 1999, p. 110).

A transformação desses elementos que proporcionam uma acumulação de capital necessária historicamente para a industrialização modificou substancialmente a economia e as relações sociais que se estabeleciam até então em uma sociedade de pequenos produtores, onde a troca não era predominante e servia apenas como intermediária para conseguir aquilo que não se produzia dentro da própria propriedade. $\mathrm{O}$ desenvolvimento do mercado e a expansão da produção nas colônias, com o comércio adquirindo uma escala regional e até de exportação para algumas regiões, possibilitaram uma acumulação de capital nas mãos de alguns comerciantes que tiveram a racionalidade para investir industrialmente. Ao estudar esse processo em Brusque, Giralda Seyferth conclui que:

Os vendeiros de Brusque, através do controle dos meios de transporte, dos preços das mercadorias, do mecanismo da conta-correntes e dos empréstimos controlavam, no início do século $\mathrm{XX}$, praticamente todas as atividades econômicas do vale do Itajaí-Mirim. Eram, pois, os únicos elementos que podiam acumular capitais que não se limitavam aos recursos reduzidos de uma pequena propriedade agrícola. Essa acumulação de capital comercial que precedeu a industrialização só foi possível, como tivemos oportunidade de mostrar, a partir da absorção da pequena propriedade dos colonos (1999, p. 116).

A partir desse momento é que se pode realizar a transformação do ca- pital mercantil em capital industrial ${ }^{9}$ : com o capital acumulado nas operações já descritas - lucro comercial, lucro financeiro e lucro da renda (aluguel) dos engenhos -, foi possível o surgimento da indústria têxtil, que teve papel fundamental na formação socioeconômica do Vale do Itajaí e de toda a região nordeste do Estado. A instalação dessa indústria em Brusque, a partir de 1892, teve como fatores de êxito outros dois elementos: a presença de mão de obra especializada - com a vinda de mestres artesãos em 1889 da região de Lodz, na Polônia, onde já trabalhavam em fábricas têxteis, por causa da crise que desempregou muitos operários; e o aumento da demanda do mercado interno, que crescia rapidamente devido ao aumento populacional das colônias e da possibilidade de exportação para outras regiões próximas.

A compreensão da gênese da industrialização e da acumulação de capital deve ser buscada a partir do processo histórico concreto e do conjunto de relações sociais que ocorrem em um espaço de tempo e lugar definidos. Desse modo, vimos que, na realidade, o processo de acumulação de capital que serviu para o desenvolvimento industrial da região não foi fruto do agricultor com sua poupança construída nem do artesão, um simples trabalhador liberal que empregava o seu trabalho nos ofícios para os quais era designado, muitas vezes recebendo mais em mercadorias do que em dinheiro. Vimos que esses personagens não possuíam condições materiais e sociais para realizarem esse tipo de empreendimento. É a partir do lucro comercial, das artimanhas finan-

\footnotetext{
O processo de transformação do capital mercantil (D - M - D+) para o capital industrial (D - M - D') é complexo. No primeiro caso, o comerciante troca dinheiro por mercadoria para depois vendê-la no mercado por mais dinheiro; ou seja, o seu lucro constitui a diferença entre o preço que ele pagou pela mercadoria e o preço pelo qual a revendeu; no segundo caso, o capitalista industrial investe dinheiro em capital constante (máquinas, matérias-primas, instalações etc.) e capital variável (trabalho assalariado). Durante o processo de produção, o capital constante apen

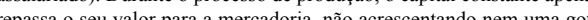
repassa o ser valor para no trabalho humano comprado pelo capitalista, não cria somente o valor necessário para a sua reprodução (subsistência). $\mathrm{O}$ trabalhador acrescenta um valor novo à mercadoria, o valor excedente, que constitui a mais-valia apropriada pelo capitalista. BRAZ, Marcelo. NETTO, José P. Economia Política: uma introdução crítica. São Paulo: Cortez, 2011.
} 
ceiras e da extração do excedente agrícola, portanto, que surge o "empreendedor". O imigrante, dessa maneira, introduziu no jogo das relações sociais uma nova forma de ser e de agir, que propunha uma ruptura com as antigas relações senhoriais dos séculos passados e que, ao mesmo tempo, projetava um desenvolvimento ulterior entrelaçado, necessariamente, com esse mesmo passado. Como analisa Florestan Fernandes:

É dentro desse contexto geral que se deve apreciar, sociologicamente, a transplantação, a assimilação e a ascensão social do imigrante. Em termos psicossociais e culturais, ele representa mais que uma ruptura com a tradição senhorial e com a dominação patrimonialista, apesar das acomodações que o levaram a compartilhar, de modos mais ou menos profundos, conforme as variações da situação de contato, interesses, valores e ideologias das elites nativas no poder. $\mathrm{O}$ imigrante introduziu no Brasil maneiras de ser, de pensar, de agir em que o "cálculo econômico" e a "mentalidade racional com relação a fins" acabaram alcançando, pela primeira vez em nosso País, a consistência estrutural e funcional requerida pelo padrão capitalista de organização da personalidade, da economia e da sociedade (2008, p. 169).

Desse modo, podemos avaliar que não apenas uma "mentalidade capitalista" europeia, mas também a inserção em um meio sócio-histórico completamente distinto do que vivenciava na Europa, modificou as motivações e formas de ser do nosso burguês, que via na possibilidade de acumular capitais, utilizando-se de todas as formas possíveis e potenciais - desde o comércio, o crédito às primeiras manufaturas, até o investimento no setor têxtil -, o modo mais rápido de poder enriquecer.

\section{Considerações finais}

O processo de transformação que vai se operar no Brasil a partir da segunda metade do século XIX - de que é expressão jurídica a proibição do tráfico de escravos e a Lei de Terras em 1850 - demonstra uma preocupação do Estado com a questão da mão de obra para a manutenção do sistema agroexportador e do principal produto na exportação mundial na época: o café. Desse modo, procurou-se atrair uma corrente de imigração para o Brasil que pudesse atender a essa demanda, ao mesmo tempo em que se estimulou a criação de núcleos de colonização no sul do país que fossem formados por pequenos proprietários capazes de produzirem alimentos para o mercado interno, "branqueassem" a população e atraíssem uma corrente "espontânea" e "abundante" de imigrantes para o país.

No entanto, o mesmo processo de "colonizar para atrair" a mão de obra livre da Europa serviu para a construção de um novo ser social, que era divergente, em parte, do antigo senhor de escravos, mas que também acabou por compartilhar com ele certos elementos do mundo senhorial do qual lutava para se diferenciar.

Nesse sentido, a análise acerca da colonização alemã no Vale do Itajaí demonstrou como o processo de industrialização que o imigrante dirigiu foi processado a partir de modos de agir em que a "racionalidade econômica" se impôs: comprar os produtos agrícolas do colono por um preço abaixo do mercado e vender mercadorias necessárias à sua reprodução por um preço acima do mercado; controlar o crédito e a poupança dos pequenos proprietários a fim de cobrar juros; e receber cerca de metade dos produtos produzidos nos engenhos e nas atafonas - o lucro comercial, o lucro financeiro e o lucro da renda (aluguel) dos engenhos - constituíram, dessa forma, uma alavanca no processo de acumulação primitiva necessária ao posterior investimento industrial. 


\section{Referências}

a) Fonte primária:

Relatório do Presidente da Província de Santa Catarina, Francisco Carlos d'Araujo Brusque, 1861.

Relatório do Presidente da Província de Santa Catarina, Adolpho de Bassos Cavalcanti de Albuquerque Lacerda, 1868.

Relatório do Presidente da Província de Santa Catarina, Andre Cordeiro de Araujo Lima, 1870.

Relatório do vice-presidente da província de Santa Catarina, Guilherme Cordeiro Coelho Cintra, 1872.

b) Fonte secundária

1. BRANCHER, A. L. História de Santa Catarina: estudos contemporâneos. Florianópolis, SC: Letras Contemporâneas, 1999. 214p.

2. BRAZ, M. NETTO, J. P. Economia Política: uma introdução crítica. São Paulo: Cortez, 2011.

3. COHN, G. W.: Sociologia. São Paulo: Editora Ática, 2008.

4. FERNANDES, F. A revolução burguesa no Brasil: ensaio de interpretação sociológica. São Paulo: Editora Globo, 2008.

5. GALEANO, E. As veias abertas da América Latina. Porto Alegre: L\&PM, 2011.

6. GOULART, F. A. Formação Econômica de Santa Catarina. Florianópolis: Editora da UFSC, 2007.

7. HERING, M. L. R. Colonização e indústria no vale do Itajaí: o modelo catarinense de desenvolvimento. Blumenau: Editora da FURB, 1987.

8. HOBSBAWN, E. A era do capital. São Paulo: Paz e Terra, 2011.
9. A era das revoluções. São

Paulo: Paz e Terra, 2010.

10. LUCKÁCS, G. Os princípios ontológicos fundamentais de Marx. São Paulo: Editora Ciências Humanas, 1972.

11. MACHADO, P. P. A política de colonização do Império. Porto Alegre: Editora Universidade/UFRGS, 1999.

12. MAMIGONIAN, A. Estudo Geográfico das indústrias de Blumenau. Revista Brasileira de Geografia. Rio de Janeiro, IBGE, 27: 389-481, 1965.

13. MAMIGONIAN, B. G. A proibição do tráfico Atlântico e a manuteção da escravidão. In: GRINBERG, Keila. SALLES, Ricardo. O Brasil Imperial - vol. I - 1808-1831. Rio de Janeiro: Civilização Brasileira, 2009.

14. MARX, K.; ENGELS, F. A Ideologia Alemã. São Paulo: Civilização Brasileira, 2007.

15. MARX, K. O Capital: crítica da economia política. São Paulo: Abril Cultural, livro I, 1985.

16. PIAZZA, W. F. A colonização de Santa Catarina. Porto Alegre: BRDE, 1982.

17. PIAZZA, W. F.; HÜBENER, L. M. Santa Catarina: história da gente. Florianópolis: Lunardelli, 1989.

18. PRADO JR., C. História Econômica do Brasil. São Paulo: Editora Brasiliense, 1976.

19. SEYFERTH, G. A colonização no Vale do Itajaí-mirim. Porto Alegre: Editora Movimento, 1999.

20. SINGER, P. Desenvolvimento Econômico e evolução urbana: análise da evolução econômica de São Paulo, Blumenau, Porto Alegre, Belo Horizonte e Recife. São Paulo: Editora Nacional, 1977.

21. VIDOR, V. Indústria e Urbanização no Nordeste de Santa Catarina. Blumenau: Editora da FURB, 1995. 